\title{
MINERALOGICAL, PHYSICOCHEMICAL AND MORPHOLOGICAL CHARACTERIZATION OF OKPELLA CLAY
}

\author{
Nurudeen SALAHUDEEN ${ }^{1 *}$, Aminat Oluwafisayo ABODUNRIN ${ }^{2}$ \\ ${ }^{1}$ Department of Chemical and Petroleum Engineering, Bayero University, Kano, Nigeria, nsalahudeen.cpe@buk.edu.ng \\ ${ }^{2}$ Department of Chemical and Petroleum Engineering, Bayero University, Kano, Nigeria
}

DOI: $10.2478 / \operatorname{minrv-2021-0037~}$

Keywords: Okpella clay, characterization, XRD, XRF, SEM, pH, Specific gravity

Abstract: Local clay mineral was mined from Okpella Town, Etsako Local Government Area of Edo State, Nigeria. Mineralogical characterization of the clay was carried out using X-ray diffraction analyzer. Chemical characterization of the clay was carried out using X-ray fluorescence analyzer and the $p H$ analysis of the clay was carried out using $\mathrm{pH}$ meter. The mineralogical analysis revealed that the clay was majorly a dolomite mineral having $72 \%$ dolomite. The impurities present are $18 \%$ cristobalite, $4.1 \%$ garnet, $5 \%$ calcite and $1 \%$ quicklime. The $\mathrm{pH}$ analysis of the clay revealed that the clay was acidic having average $\mathrm{pH}$ value of 3.9. The pH determined for the 1:1, 1:2, 1:4, 1:8 and 1:10 samples were 3.61, 3.85, 3.85, 4.05 and 4.09, respectively.

\section{Introduction}

Clay is a naturally occurring powder mineral formed by the weathering action of rocks, majorly granite feldspathic and igneous rocks [1]. Clay minerals are layered type hydrous aluminosilicates. Their chemical structures are made of layers of silica and alumina sheets stacked upon each other in a specific pattern. Particle size of clay mineral is in the range of $1-2 \mu \mathrm{m}$. Clay minerals are the major constituent of fine-grained sediments and rocks [2,3]. Clay minerals possess different classifications based on the number of alumina and silica sheets involved in their structural architecture. The major structural classifications of clay are the 1:1 and 1he 1:2 structural types. The structural classifications of clay determine their mineral categories which include kaolinite, montmorillonite, illite, vermiculite and chlorite [1]. Each of these classifications of clay possess their unique properties which make them preferable in some specific industrial applications where clay is needed. However, clay generally possess a set of excellent properties that make them suitable for a wide industrial and domestic applications. These properties include plasticity, chemical and temperature resistance, malleability, and complex composite formulations.

Clay is used in a variety of industrial applications such as including paper processing, cement manufacturing, chemical filtration, water treatment, cement manufacturing, paint processing, agricultural soil treatment, ceramic processing and building and road construction. [4, 5, 6]. Clay and other clay-like materials such as dolomite and limestone powder have been widely used as supplementary cementitious material (SCM) in the modern construction industry $[7,8,9]$.

Dolomites are subsurface cements and replacements that form below active phreatic zone reflux and mixing zones in permeable intervals flushed by warm to hot magnesium-enriched basinal and hydrothermal waters [10]. Dolomite is a natural mineral found in seabed and rock deposits among others. Dolomite chemical structure contains layers of carbonate separated by alternating layers of calcium and magnesium ions make up the ideal structure of stoichiometric dolomite $[11,12]$. The mineral name got its origin as a name in honour of a French geologist Deodat Guy de Dolomieu [13]. Dolomite belongs to the flux and building minerals category and is used in the iron and steel and Ferro-alloys industries [14]. Dolomite is chemically represented as $\mathrm{CaCO}_{3} \cdot \mathrm{MgCO}_{3}$ and it theoretically contains $54.35 \%$ of $\mathrm{CaCO}_{3}$ and $45.65 \%$ of $\mathrm{MgCO}_{3}[13,14,15]$. Although, in nature dolomite does not occur in this precise proportion due to presence of impurities. Therefore, the rock having $40-45 \% \mathrm{MgCO}_{3}$ is commonly referred to as dolomite.

\footnotetext{
* Corresponding author: Nurudeen Salahudeen, Assoc. Prof., Bayero University, Kano, Nigeria, (PMB 3011, Gwarzo

Road Kano, Nigeria, nsalahudeen.cpe@ buk.edu.ng)
} 
This study is aimed at determining the mineralogical and chemical characteristics of Okpella clay so as to provide an informed insight on its economic viability in terms of determining its suitable industrial application.

\section{Materials and methods}

\subsection{Materials}

Okpella clay was collected from Okpella deposit, Etsako Local Government Area of Edo State, Nigeria. Equipment used include X-ray Diffraction machine (Model; Rigaku MiniFlex), scanning electron microscopy (Model; Phenom ProX), weighing balance and X-ray fluorescence machine (Model; SKYRAY-EDX3600B). Other apparatus and materials used include $\mathrm{pH}$ meter and glassware.

\subsection{Methods}

Sample to be analyzed was pulverized to powder size and pressed to make thin layer which was placed in a flat sample holder of the XRD machine. XRD scan was carried out at Bragg's angle range of $5^{\circ}-70^{\circ}$ with a Bragg's angle interval of 0.026261 at 8.67 seconds per step. The X-ray tube was operated at $40 \mathrm{~mA}$ and 45 VA. X-ray fluorescence analysis was conducted using SKYRAY-EDX3600B. Scanning electron microscopy (SEM) was carried out using Phenom ProX Desktop SEM. Sample wafer was placed in the sample chamber of the SEM machine and the SEM gun was focused on a selected area of the sample at certain magnification. The electron gun shot a beam of high energy electrons on the focused area to generate a SEM micrograph of the sample. $\mathrm{pH}$ analysis was conducted by inserting the electrode of $\mathrm{pH}$ meter in clay-water mixture. Various samples of clay-water mixtures using $10 \mathrm{~g}$ constant weight of clay in varying weight of water to make 1:1, 1:2,1:4, 1:8 and 1:10; wt \%-wt $\%$ of clay-to-water were prepared and analyzed.

\section{Results and discussion}

\subsection{X-ray diffraction analysis}

Figure 1 shows both the qualitative and quantitative XRD analysis of Okpella clay. The qualitative analysis present results of the Bragg's angle in degree against the intensity in count of the various mineral present in the clay. Analysis of the quantitative XRD revealed that Dolomite phase was identified at Bragg's angle values of $31.06^{\circ}, 41.28^{\circ}$ and $51.13^{\circ}$. Quartz (Cristobalite) phase was identified at Bragg's angle values of $21.66^{\circ}$ and $69.11^{\circ}$. The peaks for Garnet phase were at Bragg's angle of $22.20^{\circ}$ and $60.0^{\circ}$. The peaks for Calcite were at Bragg's angle of $29.63^{\circ}$ and $45.04^{\circ}$. The peaks for Quicklime were at Bragg's angle of $33.6^{\circ}$ and $37.33^{\circ}$. The quantitative XRD analysis shown as the pie chart in Figure 1 revealed quantities of the various minerals present in the clay. It could be observed that Dolomite, Quartz (Cristobalite), Garnet, Calcite and Quicklime were present at $72 \%, 18 \%, 4.1 \%, 5 \%$ and $1 \%$, respectively.

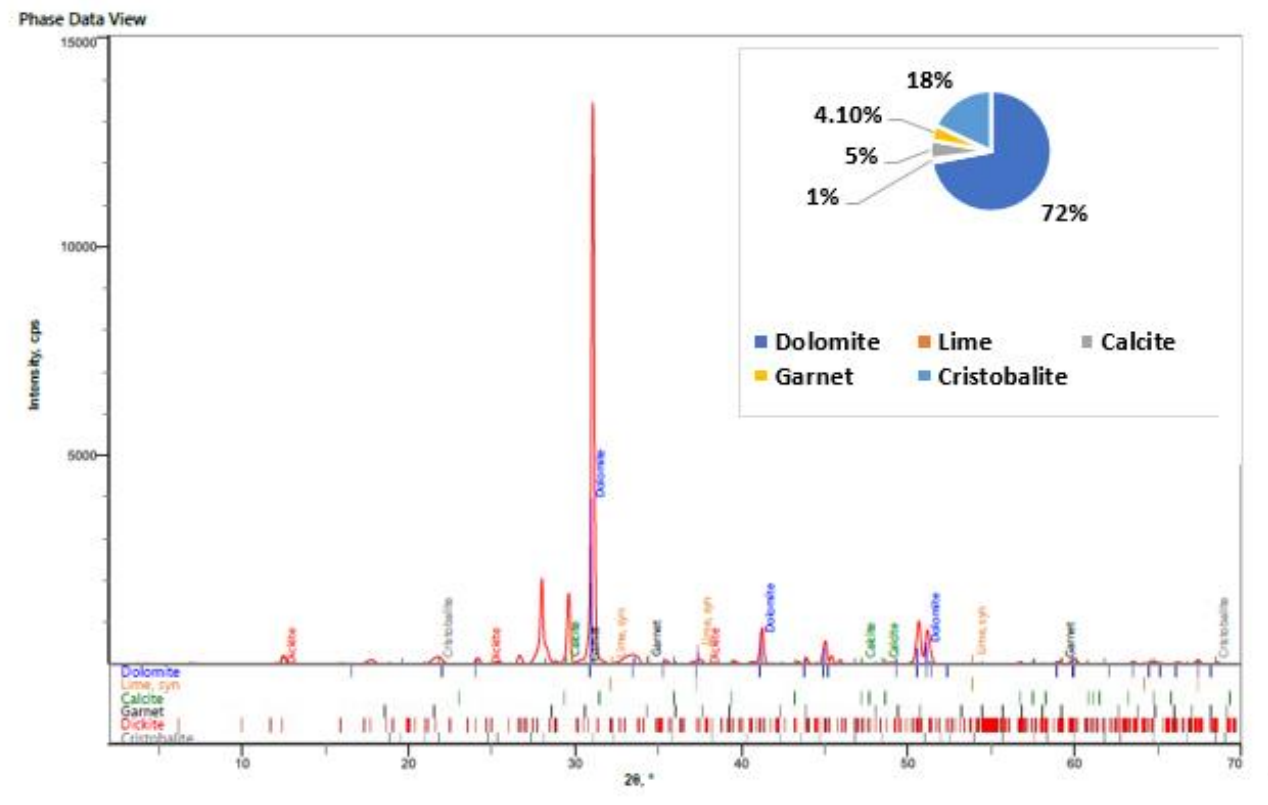

Figure 1. X-ray Diffraction of Okpella clay 


\section{2. $X$-ray fluorescence analysis}

Table 1 presents the XRF chemical composition analysis of Okpella clay. The $\mathrm{SiO}_{2}$ content of the clay was $37.4 \mathrm{wt} \%$ and the $\mathrm{AL}_{2} \mathrm{O}_{3}$ content was $7.6 \mathrm{wt} \%$. The silica-alumina content of the clay was high having value of 4.9. of $41.61 \%$. Although the silica and alumina content of the clay were higher than values reported for pure dolomite [14], the silica-alumina ratio falls within reported values [14]. $\mathrm{CaO}$ was the highest metallic oxide having value of $42.6 \mathrm{wt} \%$, this is consistent with report by other researchers $[13,14]$. The high $\mathrm{CaO}$ content further validates the XRD result showed that dolomite was the highest single-phase mineral present in Okpella clay. The other substantial metallic oxides compositions of the clay were $\mathrm{MgO}$ and $\mathrm{Na}_{2} \mathrm{O}$ which were present at 7.5 and $3.8 \mathrm{wt} \%$, respectively. The $\mathrm{MgO}$ which is also a key chemical constituent of dolomite was lower in the current study than $12.8 \mathrm{wt} \%$ reported by Pradeep et al., [14] for a pure dolomite. The substantial presence of $\mathrm{Al}_{2} \mathrm{O}_{3}$ was as a result of alumina presence in garnet while high $\mathrm{SiO}_{2}$ was due to its presence in the cristobalite impurity. Other metallic oxides such as $\mathrm{K}_{2} \mathrm{O}, \mathrm{Fe}_{2} \mathrm{O}_{3}, \mathrm{TiO}_{2}, \mathrm{P}_{2} \mathrm{O}_{5}$ and $\mathrm{SrO}$ were only present in trace quantities less than $0.3 \mathrm{wt} \%$. Their presence could be attributed to the presence of associated impurities in the clay.

Table $1 \mathrm{X}$-ray fluorescence analysis of Okpalla clay

\begin{tabular}{|c|c|}
\hline Metalic Oxide & wt\% \\
\hline $\mathrm{CaO}$ & 42.6 \\
\hline $\mathrm{SiO}_{2}$ & 37.2 \\
\hline $\mathrm{Al}_{2} \mathrm{O}_{3}$ & 7.6 \\
\hline $\mathrm{MgO}$ & 7.5 \\
\hline $\mathrm{Na}_{2} \mathrm{O}$ & 3.8 \\
\hline $\mathrm{SO}_{3}$ & 0.3 \\
\hline $\mathrm{K}_{2} \mathrm{O}$ & 0.2 \\
\hline $\mathrm{Fe}_{2} \mathrm{O}_{3}$ & 0.2 \\
\hline $\mathrm{TiO}_{2}$ & 0.1 \\
\hline $\mathrm{La}_{2} \mathrm{O}_{3}$ & 0.1 \\
\hline $\mathrm{P}_{2} \mathrm{O}_{5}$ & 0.1 \\
\hline $\mathrm{SrO}$ & 0.1 \\
\hline
\end{tabular}

\section{3. pH analysis}

Table 2 presents the $\mathrm{pH}$ analysis of Okpella clay. It could be observed that at the various water to clay ratio the $\mathrm{pH}$ was at acidic range having the lowest value of 3.61 at the 1:1 ratio sample. The $\mathrm{pH}$ value increased marginally with increase in the water content of the clay-water mixture. The highest value was recorded at 1:10 sample having $\mathrm{pH}$ value of 4.09. Using Equation (1) the average $\mathrm{pH}$ of the clay was determined as 3.9. The acidic $\mathrm{pH}$ of the clay suggested that the clay originated from weathering of igneous rock [16]. Also, the acidic $\mathrm{pH}$ was possibly due to presence of some acidic impurities which may be sulphate salt as the presence of $0.3 \mathrm{wt} \%$ of $\mathrm{SO}_{3}$ was confirmed in the XRF result of the clay.

Table 2. $\mathrm{pH}$ analysis of Okpella clay at varying ratio of clay-water mix

\begin{tabular}{|l|l|l|l|l|l|}
\hline Clay-water ratio & $1: 1$ & $1: 2$ & $1: 4$ & $1: 8$ & $1: 10$ \\
\hline pH & 3.61 & 3.85 & 3.85 & 4.05 & 4.09 \\
\hline
\end{tabular}

Average $\mathrm{pH}=\frac{\sum p H}{n}=\frac{19.45}{5}=3.9$

\subsection{Scanning electron microscopy}

Figures 2(A), 2(B), 2(C) and 2(D) show the SEM micrographs of Okpella clay at 300x, 500x, 1000x and 1500x magnifications, respectively. Analysis of the micrograph shows that the clay possessed dispersed morphology having tetrahedral crystal shape with some level of crystal defects. The average particle size was estimated to be $350 \mu \mathrm{m}$. 


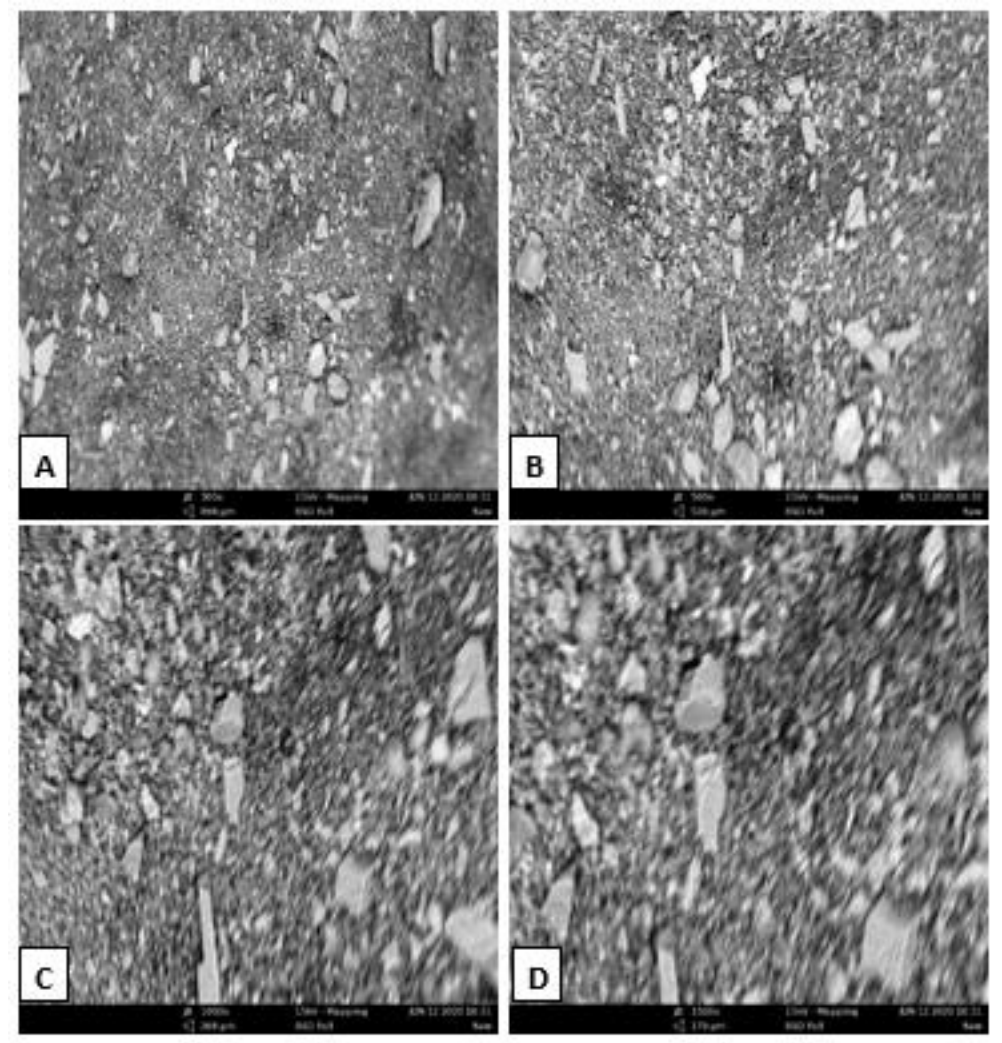

Figure 2. SEM image of Okpella clay at; (A) 300x magnification; (B) 500x magnification (C) 1000x magnification; (D) 1500x magnification

\section{Conclusion}

Mineralogical characterization of Okpella clay has shown that the clay is a dolomite mineral consisting of $72 \%$ dolomite. Other impurity phases present in the clay were cristobalite, garnet, calcite and quicklime, they were present by $18 \%, 4.1 \%, 5 \%$ and $1 \%$, respectively. Chemical characterization of the clay further confirmed presence of dolomite as indicated by substantial content of $\mathrm{CaO}$ and $\mathrm{MgO}$ at 42.6 and $7.5 \mathrm{wt} \%$, respectively. The XRF analysis further confirmed presence of cristobalite and quicklime as impurity phases present in the clay as indicated by the substantial $\mathrm{SiO}_{2}$ and $\mathrm{Na}_{2} \mathrm{O}$ content of 37.2 and $3.8 \mathrm{wt} \%$, respectively. Although, Okpella clay was majorly a dolomite mineral it also contained some impurity minerals which were responsible for the its higher $\mathrm{Al}_{2} \mathrm{O}_{3}$ and $\mathrm{SiO}_{2}$ content compared to reported values [14] for a pure dolomite. SEM Analysis of Okpella clay has shown that the clay possessed dispersed morphology having defective tetrahedral crystal shape. The $\mathrm{pH}$ determined for the 1:1, 1:2, 1:4, 1:8 and 1:10 clay-water mixture samples were $3.61,3.85,3.85,4.05$ and 4.09 , respectively. The average $\mathrm{pH}$ of the clay was 3.9 . The acidic $\mathrm{pH}$ of the clay suggested that the clay originated from weathering of igneous rock [16]. The acidic $\mathrm{pH}$ of the clay could also be due to presence of acidic salt impurity which was likely a sulphate salt as suggested by the XRF result which shows presence of $0.36 \mathrm{wt} \% \mathrm{SO}_{3}$. In view of the findings of this study Okpella dolomite is recommended as a good raw material for production of cement. The dolomite content can even be improved if beneficiation of the clay is carried out.

\section{References}

[1] Raj M., Binoy S., Kumuduni N.P., Jaffer Y.D., Nanthi S.B., Sanjai, J.P., Christian S., Yong S.O., 2021 Natural and engineered clays and clay minerals for the removal of poly-and perfluoroalkyl substances from water: Stateof-the-art and future perspectives. Advances in Colloid and Interface Science, Vol. 297, No.1, pp. 102537.

[2] Zunino F., Scrivener K., 2020

Increasing the kaolinite content of raw clays using particle classification techniques for use as supplementary cementitious materials. Construct and Building Materials, Vol. 244, No. 1, pp. 118335.

[3] Huggett J.M., 2015

Clay Minerals, Reference Module in Earth Systems and Environmental Sciences. Elsevier, Amsterdam. 
[4] Liu P., Farzana R., Rajarao R., Sahajwalla V., 2017

Lightweight Expanded Aggregates from the Mixture of Waste Automotive Plastics and Clay. Construction and Building Materials, Vol. 145, pp. 283-291.

[5] Salahudeen N., 2018

Metakaolinization effect on thermal and physiochemical properties of kankara kaolin. International Journal of Applied Science and Technology, Vol. 11, No. 2, pp. 127-135.

[6] Hassan M.D., 2014

Geochemistry and Origin of the Cretaceous Sedimentary Kaolin Deposits, Red Sea, Egypt. Geochemistry, Vol. 74, pp. 195-203.

[7] Khan M.S.H., Nguyen Q.D., Castel A., 2020

Performance of limestone calcined clay blended cement-based concrete against carbonation. Advance Cement Research, Vol. 32 No. 11, pp. 481-491.

[8] Krishnan S., Emmanuel A.C., Shah V., Parashar A., Mishra G., Maity S., Bishnoi S., 2019

Industrial production of limestone calcined clay cement: experience and insights. Green Mater. Vol. 7, pp. 15-27.

[9] Kazeem D M., John T.K., Adewumi J.B., Oladimeji B.O., 2021

Comparative performance of limestone calcined clay and limestone calcined laterite blended cement concrete. Cleaner Engineering and Technology, Vol. 4, pp, 100264.

[10] Qiao Z.F., Zhang S.N., Shen A.J., Shao G.M., She M., Cao P., Sun X.W., Zhang J., Guo R.X., Tan X.C., 2021 Features and Origins of Massive Dolomite of Lower Ordovician Penglaiba Formationin the Northwest Tarim Basin Evidence from Petrography and Geochemistry, Petroleum Science, In press, https://doi.org/10.1016/j.petsci.2021.03.001

[11] Kumar B.P., Babu K.R., Rajasekhar M., Ramachandra M., 2020

Identification of land degradation hotspots in semiarid region of Anantapur district, Southern India, using geospatial modeling approaches, Modeling Earth Systems and Environment, Vol. 6 No. 3, pp. 1841-1852.

[12] Madhu T., Kumari O.V., Kumar G.R., Reddy E.C., 2019

Analysis of Geological Factors for Successful Dolomite Mining Exploration at Venkatampalli Village, Narpala Mandal, Anantapur District, Andhra Pradesh. Bulletin of Pure \& Applied Sciences-Geology, Vol. 38 No. 2, pp. 218-224.

[13] Warren J., 2000

Dolomite: occurrence, evolution and economically important associations, Earth-Science Reviews, Vol. 52, pp. 1-81.

[14] Pradeep K.B., Raghu B.K., Sree P.P., Rajasekhar M., 2020

Occurrence and structures of dolomites in North Eastern part of Anantapur district, and their use in engineering materials. Materials Today: Proceedings, In press. https://doi.org/10.1016/j.matpr.2021.07.335.

[15] Wang Z., Torres M., Paudel P., Hu L., Yang G., Chu X., 2020

Assessing the Karst Groundwater Quality and Hydrogeochemical Characteristics of a Prominent Dolomite Aquifer in Guizhou. China. Water, Vol. 12, No. 9, pp. 2584.

[16] Keller W.D., Matlack K., 1990

The $\mathrm{pH}$ of clay suspensions in the field and laboratory, and methods of measurement of their $\mathrm{pH}$. Applied Clay Science, Vol. 5, pp. 123-133.

This article is an open access article distributed under the Creative Commons BY SA 4.0 license. Authors retain all copyrights and agree to the terms of the above-mentioned CC BY SA 4.0 license. 